Tetrahedron Lett. 2008, 49, 4571-4574

\title{
Efficient one-pot synthesis of 1-alkoxy-2-arylaminoimidazolines from N-alkoxy-N-(2-aminoethyl)-2-nitrobenzenesulfonamides and arylisothiocyanates
}

\author{
Ainhoa Mascaraque ${ }^{\S}$ Lidia Nieto,${ }^{\S}$ and Christophe Dardonville ${ }^{*}$ \\ Instituto de Química Médica, CSIC, Juan de la Cierva 3, E-28006 Madrid, Spain
}

\begin{abstract}
A new synthetic approach towards 1-alkoxy-2-aminoimidazolines that uses $N$-alkoxy- $N$-(2-aminoethyl)-2nitrobenzenesulfonamides as nucleophile reagents for the reaction with isothiocyanates is reported. Hence, the synthesis of 1-alkoxy-2aminoimidazolines was performed in high yield with a one pot procedure involving thiourea formation, nosyl group removal and spontaneous cyclization ( $42-77 \%$ overall yield).
\end{abstract}

Our continuous effort in the search of new antitrypanosomal agents potentially useful against $T$. brucei rhodesiense, ${ }^{1-3}$ the protozoan parasite responsible for the acute form of sleeping sickness in sub-saharian Africa, led us to envisage the synthesis of compounds bearing 1alkoxy-2-aminoimidazolyl groups as potential prodrugs for the 2-aminoimidazoline cation. We previously showed that the ip administration of a bis(2-aminoimidazoline) derivative was able to cure two models of acute infection in mice.i.e., T. b. brucei STIB 795 and T. b. rhodesiense STIB900. ${ }^{3}$ However, our lead compound $(\mathrm{X}=\mathrm{NH}$, Chart 1) could not cure the late stage disease (i.e., with CNS involvement) probably due to a poor blood brain barrier $(\mathrm{BBB})$ penetration caused by its dicationic nature.

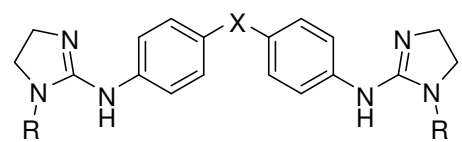

$\mathrm{R}=\mathrm{H}$ : Antitrypanosomal lead compounds $\mathrm{R}=\mathrm{OH}, \mathrm{O}$-alkyl, OBn: target compounds Chart 1
In fact, this kind of guanidine compounds has very basic nitrogen atoms $(\mathrm{pKa}=9.9 \text { for our lead compound })^{4}$ that are charged at physiological $\mathrm{pH}$ and as such potentially poorly liposoluble, leading to poor diffusion across the BBB.

Among the existing strategies to improve the pharmacokinetics of cationic compounds such as amidines or guanidines, the substitution of the basic $\mathrm{N}$-atom with hydroxyl (or alkoxy group) or ester groups, affording less basic molecules that are not protonated at physiological $\mathrm{pH}$, has been successfully applied to antimicrobials. In particular, the amidoxime prodrug strategy developed by Clement and co-workers ${ }^{5}$ and used by the group of Boykin and Tidwell to improve the oral bioavailablity of a series of 2,5-bis(4-amidinophenyl)furan derivatives is a very promising approach ${ }^{6-9}$ that proved also useful for the CNS delivery of the diamidine antitrypanosomal agents DB844 and DB289. ${ }^{10-12}$

Encouraged by this data, we considered the preparation of 1-alkoxy-2-aminoimidazoline derivatives that could work as potential prodrugs for the 2-aminoimidazoline group. Since our lead compounds (Chart 1) are easily

\footnotetext{
* Corresponding author. Tel.: +34 912587490; Fax.: +34 915644853; e-mail: dardonville@iqm.csic.es

$\S$ Both authors contributed equally to this work.
} 
accessible via their Boc-protected precursors, obtained by reaction between primary diamines and N,N'-bis(tertbutoxycarbonyl)imidazoline-2-thione/ $\mathrm{HgCl}_{2} / \mathrm{Et}_{3} \mathrm{~N}$, ${ }^{13}$ we were especially interested in a methodology using the same commercially available aromatic amines as starting materials. However, and contrary to $\mathrm{N}$ hydroxyguanidines, ${ }^{14-16}$ only a few procedures for the preparation of 1-hydroxy-2-aminoimidazolines and their $O$ alkyl derivatives could be found, mainly in the patent literature where no yields were reported (Equation 1). ${ }^{17-22}$

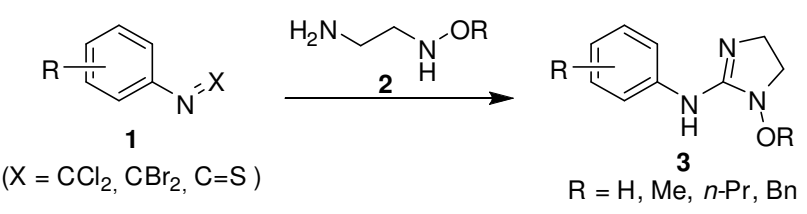

Equation 1

\section{Results and discussion}

None of the methods mentioned above resulted convenient for the preparation of our target compounds due in part to the difficulty to get the N-alkoxyethylenediamine precursors (2) easily and in high yields. For instance, 4a was obtained satisfactorily from 2bromoethylphthalimide/O-benzylhydroxylamine following the reported procedure, ${ }^{20}$ but several attempts to synthesise the corresponding methyl (4b) and ethyl (4c) analogues $\left[\mathrm{RONH}_{2} \cdot \mathrm{HCl}\right.$ ( 2 equiv)/ DIPEA ( 2 equiv)/ $\mathrm{CH}_{3} \mathrm{CN}, 80^{\circ} \mathrm{C}$, 2 days] resulted only in low yields $(20 \%)$ of the product together with a major dione by-product (4d and $4 \mathbf{e}$, respectively). This result is probably due to the unstability of $\mathbf{4 b}$ and $\mathbf{4 c}$ in the basic reaction medium, resulting in the intramolecular nucleophilic attack of the $N$-alkoxyamine at the phthalimide carbonyl group. ${ }^{23}$<smiles>[R9]ONCCN1C(=O)c2ccc(C3CN(O)C4(O)c5ccccc5C(=O)N4C3)cc2C1=O</smiles>

The fact that this rearrangement was not observed with 4a is possibly due to steric factors with the bulkier benzyl group. The use of a base to deprotonate the hydrochloride salt of the alkoxylamine reagent in the reaction medium may also favour the rearrangement. ${ }^{23}$

We found that protecting the secondary amine with the 2-nitrobenzenesulfonamide (Ns) $\operatorname{group}^{24,25}$ was a very convenient way to avoid the problem of rearrangement of 4a and $\mathbf{4 b}$ through intramolecular cyclization. Thus, $O$ alkyl- $N$-nosyl hydroxylamines $\mathbf{5 a}-\mathbf{8 a}$ were prepared easily, in good yields, by sulfonylation $\left(\mathrm{NsCl} /\right.$ pyridine/ $\mathrm{CH}_{2} \mathrm{Cl}_{2}$ ) of hydroxylamines $\mathbf{5}, \mathbf{6}, 7^{26}$ and $\mathbf{8}$, respectively, followed by acidic workup and crystallization from acetone/hexane $\mathrm{e}^{27}$ (Scheme 1).

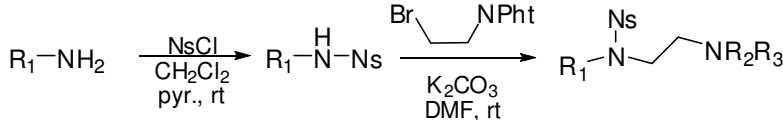

$$
\begin{aligned}
& \begin{array}{llll}
\mathbf{5}: \mathrm{R}_{1}=\mathrm{OMe} & \mathbf{5 a}(75 \%) & \mathbf{5 b}(92 \%) & \mathbf{5 c}(97 \%) \\
\mathbf{6}: \mathrm{R}_{1}=\mathrm{OEt} & \mathbf{6 a}(76 \%) & \mathbf{6 b}(95 \%) & \mathbf{6 c}(81 \%)
\end{array} \\
& \text { 6: } \mathrm{R}_{1}=\mathrm{OEt} \\
& \text { 7: } \mathrm{R}_{1}=\mathrm{OTHP} \\
& \text { 8: } R_{1}=O B n \\
& \begin{array}{l}
\text { 6a }(76 \%) \\
7 a(77 \%) \\
8 a(73 \%)
\end{array} \\
& 7 \mathrm{~b}(98 \%) \quad 6 \mathrm{c}(81 \%) \\
& 8 \text { b }(97 \%) \\
& \mathrm{R}_{2}=\mathrm{R}_{3}=\mathrm{Pht} \quad \mathrm{R}_{2}=\mathrm{R}_{3}=\mathrm{H}
\end{aligned}
$$$$
\text { Scheme } 1
$$

The 2-nitrobenzenesulfonamides $\mathbf{5 a}-\mathbf{8 a}$ were alkylated at room temperature with 2-bromoethylphthalimide to give high yield of the corresponding 2nitrobenzenesulfonamides $\mathbf{5 b}-\mathbf{8 b}$ as colorless solids. ${ }^{28}$ In most cases, the products were obtained in sufficient purity ( $>95 \%$ by HPLC) by water-mediated precipitation from the reaction mixture. ${ }^{29}$ The phthalimide protecting group was removed easily by treatment with an excess of hydrazine monohydrate in EtOH affording $\mathbf{5 c}-\mathbf{8 c}{ }^{30}$ The non-optimized overall yield for the three step synthesis of the $N$-alkoxy- $N$-nosyl-2-aminoethane derivatives was pretty satisfying (ca. $60 \%$ ).

It should be noted that, upon storage as free base, these primary amines tend to rearrange to cyclic secondary amines (5d-8d) via an intramolecular process. This reaction presumably occurs either by direct intramolecular aromatic nucleophilic substitution of the nitro group or possibly through Smiles rearrangement followed by an annulation process with concomitant loss of nitrous acid. $^{31,32}$ This drawback can be overcome simply if the reagent is stored as its phthalimide precursor $\mathbf{5 b}-\mathbf{8 b}$ and the amino group is deprotected immediately before use.

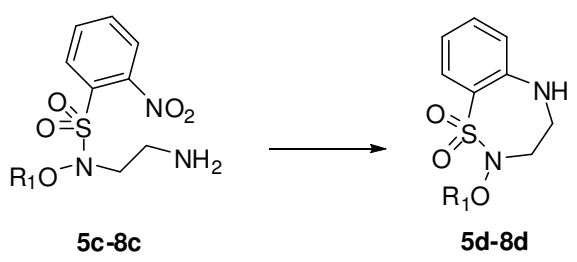

Phenylisothiocyanate was chosen as a model compound to test this synthetic approach (Scheme 2). A screening of the reaction conditions for the condensation of $\mathbf{5 c}$ with phenylisothiocyanate showed that 1.5 equiv. of amine 5c were necessary whereas the addition of base (DIPEA), heating of the reaction or changing the solvent (THF, $\mathrm{CH}_{3} \mathrm{CN}$, toluene) did not modify significantly the yield of the formation of $\mathbf{9}$. On the contrary, the dropwise addition of a dilute solution of the isothiocyanate to the amine was critical to avoid the formation of large amounts of 1,3diphenylthiourea by-product. 


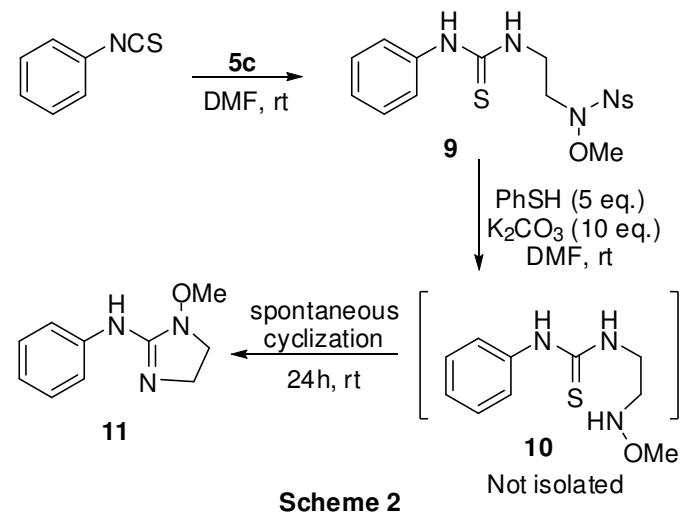

We were pleased to verify that there is no need to isolate the thiourea intermediate in order to complete this synthetic route. Indeed, after checking the complete formation of 9 by HPLC-MS, the crude reaction mixture was treated with $\mathrm{PhSH}$ (5 equiv)/ $\mathrm{K}_{2} \mathrm{CO}_{3}$ (10 equiv) ${ }^{33}$ following Fukayamas' protocol. ${ }^{24}$ In this way, 9 was converted directly to the 1methoxy-2-phenylaminoimidazoline product 11 via formation of the amine intermediate $\mathbf{1 0}(77 \%$ for 3 steps). This new protocol was validated with the synthesis of the target compounds 12-15 (scheme 3 ) in moderate to high yield $\left(42^{34}-74 \%\right){ }^{35}$ It should be noted that in this case, i.e. synthesis of symmetric bis-imidazolines, the last step required longer reaction time (ca. 3 days) in order to complete the cyclization of the amino-thiourea intermediate. Alternatively, heating the reaction vessel at $65{ }^{\circ} \mathrm{C}$ allowed the cyclization to occur in approximately 4 h. $^{36}$
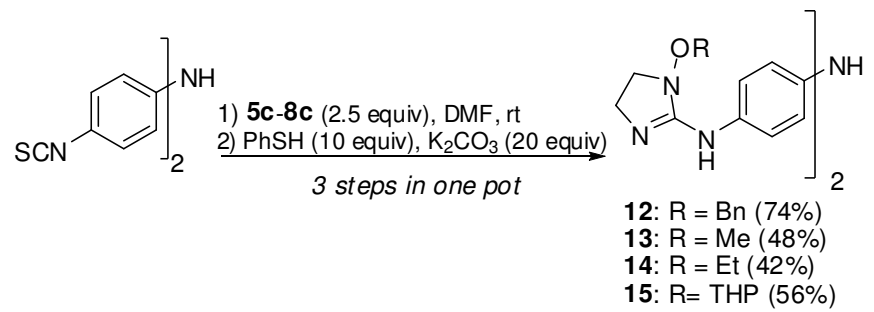

Scheme 3

In summary, we have reported a new methodology that is very convenient for the synthesis of 1-alkoxy-2aminoimidazoline derivatives starting from $N$-alkoxy- $N$ - $(2-$ aminoethyl)-2-nitrobenzenesulfonamides that are easily obtained in high yield in three steps from commercial hydroxylamines. This method proved practical for the one pot synthesis of mono- and bis(1-alkoxy-2arylamino)imidazolines in good yield (42-77\% total yield from the starting isothiocyanate).

\section{Acknowledgments}

This work was supported by the "Proyecto Intramural Especial" grant 200680I121 from the CSIC (LN and AM) and the "Programa Nacional de Biomedicina" grant
SAF2006-04698 from the Spanish "Ministerio de Educación y Ciencia”.

\section{References}

1. C. Dardonville and R. Brun, J. Med. Chem. 2004, 47, 22962307.

2. C. Dardonville, L. Nieto, F. Rodriguez, I. Rozas, M. Kaiser, R. Brun, B. Nguyen, W. D. Wilson and R. N. García, COST B22 Annual Congress on Drug Development for Parasitic Diseases, Dundee, 2007.

3. C. Dardonville, M. P. Barrett, R. Brun, M. Kaiser, F. Tanious and W. D. Wilson, J. Med. Chem. 2006, 49, 3748-3752.

4. G. K. Kinsella, F. Rodriguez, G. W. Watson and I. Rozas, Bioorg. Med. Chem. 2007, 15, 2850-2855.

5. B. Clement, Drug Metab. Rev. 2002, 34, 565-579.

6. M. A. Ismail, R. Brun, T. Wenzler, F. A. Tanious, W. D. Wilson and D. W. Boykin, Bioorg. Med. Chem. 2004, 12, 5405-5413.

7. M. A. Ismail, R. Brun, T. Wenzler, F. A. Tanious, W. D. Wilson and D. W. Boykin, J. Med. Chem. 2004, 47, 36583664.

8. S. M. Rahmathullah, J. E. Hall, B. C. Bender, D. R. McCurdy, R. R. Tidwell and D. W. Boykin, J. Med. Chem. 1999, 42, 3994-4000.

9. D. W. Boykin, A. Kumar, J. E. Hall, B. C. Bender and R. R. Tidwell, Bioorg. Med. Chem. Lett. 1996, 6, 3017-3020.

10. L. M. Sturk, J. L. Brock, C. R. Bagnell, J. E. Hall and R. R. Tidwell, Acta Trop. 2004, 91, 131-143.

11. L. Sturk, J. E. Hall, J. A. Holman, C. Kalvass and R. R. Tidwell, Drug Metab. Rev., 2003, 35, 39-39.

12. M. N. C. Soeiro, E. M. De Souza, C. E. Stephens and D. W. Boykin, Expert Opin. Investig. Drugs 2005, 14, 957-972.

13. C. Dardonville, P. Goya, I. Rozas, A. Alsasua, M. I. Martin and M. J. Borrego, Bioorg. Med. Chem. 2000, 8, 1567-1577.

14. A. R. Katritzky, N. M. Khashab, S. Bobrov and M. Yoshioka, J. Org. Chem. 2006, 71, 6753-6758.

15. N. I. Martin, J. J. Woodward and M. A. Marletta, Org. Lett. 2006, 8, 4035-4038.

16. P. G. Wang, M. Xian, X. Tang, X. Wu, Z. Wen, T. Cai and A. J. Janczuk, Chem. Rev. 2002, 102, 1091-1134.

17. F. Jung, C. Delvare, D. Boucherot and A. Hamon, Tetrahedron Lett. 1989, 30, 2375-2378.

18. Germany Pat., 2709720, 1978.

19. S. B. Jonnalagadda, V. Choudary and A. K. Bhattacharya, J. Chem. Soc., Perkin Trans. 2 1983, 849 - 853.

20. US Pat., 4244957, 1978.

21. Brit. Pat., 2083475, 1981.

22. A. Alanine, A. Bourson, B. Buttelmann, R. Gill, M. P. Heitz, V. Mutel, E. Pinard, G. Trube and R. Wyler, Bioorg. Med. Chem. Lett. 2003, 13, 3155-3159.

23. O. Núñez, J. Rodríguez and L. Angulo, J. Phys. Org. Chem. 1993, 7, 80-89.

24. T. Fukuyama, C.-K. Jow and M. Cheung, Tetrahedron Lett. 1995, 36, 6373-6374.

25. T. Kan and T. Fukuyama, J. Syn. Org. Chem. Jpn 2001, 59, 779-789.

26. US Pat., US4604407, 1986.

27. P. A. Reddy, O. F. Schall, J. R. Wheatley, L. O. Rosik, J. P. McClurg, G. R. Marshall and U. Slomczynska, Synthesis 2001, 1086-1092.

28. General procedure for the synthesis of $\mathbf{5 b}-\mathbf{8 b} . \mathrm{K}_{2} \mathrm{CO}_{3}(709$ $\mathrm{mg}, 5.1 \mathrm{mmol}, 2$ equiv.) was added to a stirred solution of sulfonamide $\mathbf{5 a}-\mathbf{8 a} \mathbf{a}^{27}(2.57 \mathrm{mmol}, 1$ equiv. $)$ and 2bromoethylphthalimide (718 mg, $2.8 \mathrm{mmol}, 1.1$ equiv.) in dry 
DMF $(4 \mathrm{~mL})$. The reaction was stirred $24 \mathrm{~h}$ at room temperature and diluted with water $(45 \mathrm{~mL})$. The precipitate was collected by filtration, rinsed thoroughly with water and dried under high vacuum, affording the $\mathbf{5 b}-\mathbf{8 b}$ as colorless solids. Compound 5b: colourless solid (92\%); mp 175.1$176.7{ }^{\circ} \mathrm{C} ; \delta_{\mathrm{H}}\left(300 \mathrm{MHz} ; \mathrm{CDCl}_{3}\right) 8.0(1 \mathrm{H}, \mathrm{dd}, J 1.5$ and 7.5 $\mathrm{Hz}), 7.89-7.68(6 \mathrm{H}, \mathrm{m}), 7.56(1 \mathrm{H}, \mathrm{dd}, J 1.1$ and 7.9$), 3.99$ $(3 \mathrm{H}, \mathrm{s}), 3.93(2 \mathrm{H}, \mathrm{t}, J 5.6), 3.42(2 \mathrm{H}, \mathrm{br}) ; \delta_{\mathrm{C}}\left(75 \mathrm{MHz} ; \mathrm{CDCl}_{3}\right)$ 168.0, 149.9, 135.1, 134.2, 132.3, 131.9, 130.9, 125.6, 123.8, 123.5, 65.8, 51.1, 35.2; $\mathrm{m} / \mathrm{z} 406.21(\mathrm{M}+\mathrm{H}, 100 \%)$; Found: $\mathrm{C}$, $50.54 ; \mathrm{H}, 3.80 ; \mathrm{N}, 10.27 ; \mathrm{S}, 8.02 . \mathrm{C}_{17} \mathrm{H}_{15} \mathrm{~N}_{3} \mathrm{O}_{7} \mathrm{~S}$ requires $\mathrm{C}$, $50.37 ; \mathrm{H}, 3.73 ; \mathrm{N}, 10.37 ; \mathrm{S}, 7.91 \%$. Compound $\mathbf{6 b}$ : colourless solid (95\%); mp $141.5-142.1{ }^{\circ} \mathrm{C} ; \delta_{\mathrm{H}}\left(300 \mathrm{MHz} ; \mathrm{CDCl}_{3}\right) 8.02$ $(1 \mathrm{H}, \mathrm{dd}, J 1.5$ and $7.5 \mathrm{~Hz}), 7.87-7.83(2 \mathrm{H}, \mathrm{m}), 7.78-7.71(4 \mathrm{H}$, $\mathrm{m}), 7.57(1 \mathrm{H}, \mathrm{dd}, 1.5$ and 7.9$), 4.26(2 \mathrm{H}, \mathrm{q}, J 7.2), 3.93(2 \mathrm{H}, \mathrm{t}$, $J$ 5.6), $3.46(2 \mathrm{H}, \mathrm{br} \mathrm{s}), 1.28(3 \mathrm{H}, \mathrm{t}, J 7.2) ; \delta_{\mathrm{C}}\left(75 \mathrm{MHz} ; \mathrm{CDCl}_{3}\right)$ 168.1, 149.8, 134.9, 134.1, 132.5, 131.9, 131.0, 125.8, 123.9, 123.5, 74.2, 51.1, 35.4, 13.6; $\mathrm{m} / \mathrm{z} 420.3(\mathrm{M}+\mathrm{H})$; Found: C, 51.84; $\mathrm{H}, 4.31 ; \mathrm{N}, 10.27 ; \mathrm{S}, 7.86 . \mathrm{C}_{18} \mathrm{H}_{17} \mathrm{~N}_{3} \mathrm{O}_{7} \mathrm{~S}$ requires $\mathrm{C}$, 51.55; H, 4.09; N, 10.02; S, 7.65\%. Compound 7b: colourless solid (98\%); mp $122.1-123.9{ }^{\circ} \mathrm{C} ; \delta_{\mathrm{H}}\left(300 \mathrm{MHz} ; \mathrm{CDCl}_{3}\right) 8.05$ $(1 \mathrm{H}, \mathrm{dd}, J 1.3$ and $7.7 \mathrm{~Hz}), 7.86-7.83(2 \mathrm{H}, \mathrm{m}), 7.77-7.69(4 \mathrm{H}$, $\mathrm{m}), 7.58(1 \mathrm{H}, \mathrm{dd}, J 1.3$ and 7.7$), 5.1(1 \mathrm{H}, \mathrm{m}), 4.20-3.65(4 \mathrm{H}$, m), 3.45 (1H, m, 1/2 AA'BB'), 3.25 (1H, m, 1/2 AA'BB'), 1.9$1.3(6 \mathrm{H} \mathrm{m}) ; \delta_{\mathrm{C}}\left(75 \mathrm{MHz} ; \mathrm{CDCl}_{3}\right) 168.1(2 \times C O), 149.4(C-$ $\left.\mathrm{NO}_{2}\right), 134.8(\mathrm{CH}), 133.9(\mathrm{CH}), 132.3(\mathrm{CH}), 132.1(\mathrm{CH})$, $127.3\left(\mathrm{C}-\mathrm{SO}_{2}\right), 123.9(\mathrm{CH}), 123.2(\mathrm{CH}), 106.1(\mathrm{OCH}), 63.8$ $\left(\mathrm{OCH}_{2}\right), 51.4\left(\mathrm{NCH}_{2}\right), 36.0\left(\mathrm{NCH}_{2}\right), 28.8\left(\mathrm{CH}_{2}\right), 24.8\left(\mathrm{CH}_{2}\right)$, $19.7\left(\mathrm{CH}_{2}\right) ; \mathrm{m} / z$ 476.34 (M+H); Found: $\mathrm{C}, 51.90 ; \mathrm{H}, 4.32 ; \mathrm{N}$, 9.06; S, 6.84. $\mathrm{C}_{21} \mathrm{H}_{21} \mathrm{~N}_{3} \mathrm{O}_{8} \mathrm{~S} \cdot 0.5 \mathrm{H}_{2} \mathrm{O}$ requires $\mathrm{C}, 52.06 ; \mathrm{H}$, $4.58 ; \mathrm{N}, 8.67 ; \mathrm{S}, 6.62 \%$. Compound 8b: colourless solid (97\%); mp $118.5-119.8^{\circ} \mathrm{C}$; two conformers were observed by ${ }^{1} \mathrm{H}$ and ${ }^{13} \mathrm{C}$ NMR in $\mathrm{CDCl}_{3}$ and DMSO- $\mathrm{d}_{6}: \delta_{\mathrm{H}}(300 \mathrm{MHz}$; $\left.\mathrm{CDCl}_{3}\right) 8.01(1 \mathrm{H}, \mathrm{dd}, J 1.5$ and $7.9 \mathrm{~Hz}), 7.89-7.83(2 \mathrm{H}, \mathrm{m})$, $7.78-7.72(3 \mathrm{H}, \mathrm{m}), 7.65(1 \mathrm{H}, \mathrm{td}, J 1.1$ and 7.9$), 7.57-7.53$ $(3 \mathrm{H}, \mathrm{m}), 7.43(3 \mathrm{H}, \mathrm{m}), 5.23(2 \mathrm{H}, \mathrm{s}), 4.11(0.1 \mathrm{H}, \mathrm{t}, J 6.8$, conformer A, minor), $3.86(0.9 \mathrm{H}$, br t, $J 5.3$, conformer $\mathrm{B}$, major), $3.62(0.1 \mathrm{H}, \mathrm{t}, J 6.8$, conformer A), $3.47(0.9 \mathrm{H}$, br, conformer B); $\delta_{\mathrm{C}}\left(75 \mathrm{MHz} ; \mathrm{CDCl}_{3}\right) 168.0(C O), 149.8(C$ $\left.\mathrm{NO}_{2}\right), 134.96(\mathrm{C}), 134.7(\mathrm{CH}), 134.1(\mathrm{CH}), 132.5(\mathrm{CH}), 131.9$ (C), $131.1(\mathrm{CH}), 129.9(\mathrm{CH}), 128.9(\mathrm{CH}), 128.6(\mathrm{CH}), 125.6$ (C), $123.8(\mathrm{CH}), 123.4(\mathrm{CH}), 80.5\left(\mathrm{OCH}_{2}\right), 51.3\left(\mathrm{CH}_{2}\right.$, conformer B), $39.1\left(\mathrm{CH}_{2}\right.$, conformer A), $35.1\left(\mathrm{CH}_{2}\right.$, conformer B), $28.0\left(\mathrm{CH}_{2}\right.$, conformer A); $m / z 482.28(\mathrm{M}+\mathrm{H})$; Found: $\mathrm{C}, 57.08 ; \mathrm{H}, 4.06 ; \mathrm{N}, 8.71 ; \mathrm{S}, 6.47 . \mathrm{C}_{23} \mathrm{H}_{19} \mathrm{~N}_{3} \mathrm{O}_{7} \mathrm{~S}$ requires $\mathrm{C}, 57.37 ; \mathrm{H}, 3.98 ; \mathrm{N}, 8.73 ; \mathrm{S}, 6.66 \%$.

29. In some experiments, a minor by-product (Scheme 1, 5b-8b: $\mathrm{R}_{1}=\mathrm{H}$ ) resulting from the cleavage of the alkoxyl group was observed. H.-G. H. Pablo Wessig, Liebigs Ann. Chem. 1991, 1991, 983-986.

30. Procedure for the deprotection of the Pht group: Excess (10 equiv) hydrazine monohydrate $\left(25 \%\right.$ in $\left.\mathrm{H}_{2} \mathrm{O}\right)$ was added to a stirred suspension of the phthalimide derivative (1.4 $\mathrm{mmol})$ in EtOH $(5 \mathrm{~mL})$. The reaction, which became clear after ca. $20 \mathrm{~min}$, was stirred at room temperature overnight. The precipitate was filtered off and rinsed with EtOH. The filtrate was concentrated to dryness and the resulting solid was taken up in $\mathrm{CH}_{2} \mathrm{Cl}_{2}$. The unsoluble white floculent solid (2,3-dihydrophthalazine-1,4-dione) was filtered off and the filtrate evaporated under vacuum to afford the crude amine as a yellowish oil that solidified on standing. The amine was dried under vacuum and used directly in the reaction with isothiocyanates in order to avoid the formation of the cyclic dione by-product upon standing. Compound $5 \mathbf{c}$ : yellowish oil $(97 \%) ; \delta_{\mathrm{H}}\left(300 \mathrm{MHz}, \mathrm{CDCl}_{3}\right) 8.03(1 \mathrm{H}, \mathrm{dd}, J 1.5$ and 7.9 $\left.\mathrm{Hz}, \mathrm{Ar}, o-\mathrm{NO}_{2}\right), 7.79\left(1 \mathrm{H}, \mathrm{td}, J 1.5\right.$ and $\left.7.9, \mathrm{Ar}, p-\mathrm{NO}_{2}\right), 7.71$ $\left(1 \mathrm{H}, \mathrm{td}, J 1.5\right.$ and $\left.7.9, \mathrm{Ar}, p-\mathrm{SO}_{2}\right), 7.57(1 \mathrm{H}, \mathrm{dd}, J 1.5$ and 7.9 ,
Ar, $\left.o-\mathrm{SO}_{2}\right), 3.87\left(3 \mathrm{H}, \mathrm{s}, \mathrm{OCH}_{3}\right), 3.14\left(2 \mathrm{H}, \mathrm{t}, J 5.6, \mathrm{NCH}_{2}\right)$, $2.95\left(2 \mathrm{H}, \mathrm{t}, \mathrm{J} 5.6, \mathrm{CH}_{2} \mathrm{NH}_{2}\right), 1.60\left(2 \mathrm{H}, \mathrm{br}, \mathrm{NH}_{2}\right) ; \delta_{\mathrm{C}}(75 \mathrm{MHz}$, $\left.\mathrm{CDCl}_{3}\right) 149.8\left(\mathrm{C}-\mathrm{NO}_{2}\right), 134.9\left(\mathrm{CH}, p-\mathrm{NO}_{2}\right), 132.4(\mathrm{CH}, o-$ $\left.\mathrm{NO}_{2}\right), 130.9\left(\mathrm{CH}, p-\mathrm{SO}_{2}\right), 125.7\left(\mathrm{C}-\mathrm{SO}_{2}\right), 123.6\left(\mathrm{CH}, o-\mathrm{SO}_{2}\right)$, $65.6\left(\mathrm{CH}_{3}\right), 56.3\left(\mathrm{NCH}_{2}\right), 39.1\left(\mathrm{CH}_{2} \mathrm{NH}_{2}\right) ; \mathrm{m} / z 276.19(\mathrm{M}+\mathrm{H}$, $100 \%)$. Compound $6 \mathrm{c}$ : yellowish oil $(81 \%) ; \delta_{\mathrm{H}}(300 \mathrm{MHz}$; $\left.\mathrm{CDCl}_{3}\right) 8.04(1 \mathrm{H}, \mathrm{dd}, J 1.1$ and $7.9 \mathrm{~Hz}, \mathrm{Ar}), 7.77(1 \mathrm{H}, \mathrm{ddd}, J$ 1.5, 7.9 and $7.5, \mathrm{Ar}), 7.72(1 \mathrm{H}$, ddd, $J 1.5,7.9$ and $7.5, \mathrm{Ar})$, $7.57\left(1 \mathrm{H}, \mathrm{dd}, J 1.1\right.$ and 7.9, Ar), $4.15\left(2 \mathrm{H}, \mathrm{t}, J 7.2, \mathrm{OCH}_{2}\right)$, $4.10\left(2 \mathrm{H}, \mathrm{m}, \mathrm{NCH}_{2}\right), 3.2\left(2 \mathrm{H}, \mathrm{br}, \mathrm{NH}_{2}\right), 2.93(2 \mathrm{H}, \mathrm{t}, J 5.7$, $\left.\mathrm{CH}_{2} \mathrm{NH}_{2}\right), 1.23\left(3 \mathrm{H}, \mathrm{t}, J 7.2, \mathrm{CH}_{3}\right) ; \delta_{\mathrm{C}}\left(75 \mathrm{MH} ; \mathrm{CDCl}_{3}\right) 149.8$, $146.6,134.9,132.5,130.9,123.7,73.9,56.5,39.2,13.5 ; \mathrm{m} / \mathrm{z}$ $\left(\mathrm{ES}^{+}\right) 290.2(\mathrm{M}+\mathrm{H}, 100 \%)$. Compound $7 \mathrm{c}$ : yellowish oil $(84$ $\%) ; \delta_{\mathrm{H}}\left(300 \mathrm{MHz}, \mathrm{CDCl}_{3}\right) 8.02(1 \mathrm{H}, \mathrm{dd}, J 1.3$ and $7.7 \mathrm{~Hz}$, $\mathrm{Ar}), 7.79(1 \mathrm{H}, \mathrm{td}, J 1.3$ and $7.7, \mathrm{Ar}), 7.71(1 \mathrm{H}, \mathrm{td}, J 1.3$ and 7.7, Ar), 7.58 ( $1 \mathrm{H}$, dd, $J 1.3$ and 7.7, Ar), $5.29\left(2 \mathrm{H}, \mathrm{s}, \mathrm{NH}_{2}\right)$, 5.16-5.13 (1H, br s, OCH), $3.93(1 \mathrm{H}, 1 / 2$ AA'BB'), 3.64-3.46 $(2 \mathrm{H}, \mathrm{m}), 3.1-3.0(1 \mathrm{H}, \mathrm{m}), 2.88-2.79(2 \mathrm{H}, \mathrm{m}), 1.91-1.53(6 \mathrm{H}$, m) ; $\delta_{\mathrm{C}}\left(75 \mathrm{MHz}, \mathrm{CDCl}_{3}\right) 150.0\left(C-\mathrm{NO}_{2}\right), 135.4\left(\mathrm{CH}, p-\mathrm{NO}_{2}\right)$, $132.9\left(\mathrm{CH}, o-\mathrm{NO}_{2}\right), 131.4\left(\mathrm{CH}, p-\mathrm{SO}_{2}\right), 126.8\left(C-\mathrm{SO}_{2}\right), 124.2$ $\left(\mathrm{CH}, \mathrm{o}-\mathrm{SO}_{2}\right), 106.0(\mathrm{OCH}), 65.1\left(\mathrm{OCH}_{2}\right), 57.0\left(\mathrm{NCH}_{2}\right), 39.2$ $\left(\mathrm{CH}_{2} \mathrm{NH}_{2}\right), 29.3 \quad\left(\mathrm{OCHCH}_{2}\right), \quad 25.4 \quad\left(\mathrm{OCH}_{2} \mathrm{CH}_{2}\right), 20.8$ $\left(\mathrm{CH}_{2} \mathrm{CH}_{2} \mathrm{CH}_{2}\right) ; \mathrm{m} / \mathrm{z} 346.11(\mathrm{M}+\mathrm{H}, 100 \%)$. Compound 8c: yellowish oil $(76 \%) ; \delta_{\mathrm{H}}\left(300 \mathrm{MHz}, \mathrm{CDCl}_{3}\right) 8.03(1 \mathrm{H}, \mathrm{d}, J 7.8$ $\mathrm{Hz}), 7.76(1 \mathrm{H}, \mathrm{dd}, J 1.9$ and 7.8$), 7.66(1 \mathrm{H}, \mathrm{t}, J 7.8), 7.60$ $7.51(1 \mathrm{H}, \mathrm{m}), 7.46-7.38(5 \mathrm{H}, \mathrm{m}), 5.09(2 \mathrm{H}, \mathrm{s}), 3.15(2 \mathrm{H}, \mathrm{br}$ m), $2.75(2 \mathrm{H}, \mathrm{t}, J 5.9), 1.48\left(2 \mathrm{H}, \mathrm{br}, \mathrm{NH}_{2}\right) ; \delta_{\mathrm{C}}(125 \mathrm{MHz}$, $\left.\mathrm{CDCl}_{3}\right) 149.8\left(C-\mathrm{NO}_{2}\right), 134.9(C, \mathrm{Ar}), 134.6\left(C-\mathrm{SO}_{2}\right), 132.6$ $\left(\mathrm{CH}, \mathrm{Ar}, p-\mathrm{NO}_{2}\right), 130.9\left(\mathrm{CH}, \mathrm{Ar}, o-\mathrm{NO}_{2}\right), 130.1(\mathrm{CH}, \mathrm{Ar}, p-$ $\mathrm{SO}_{2}$ ), 129.2 ( $\left.\mathrm{CH}, \mathrm{Ar}\right), 128.7$ ( $\left.\mathrm{CH}, \mathrm{Ar}\right), 123.7$ ( $\mathrm{CH}, \mathrm{Ar}, o-$ $\left.\mathrm{SO}_{2}\right), 80.1\left(\mathrm{OCH}_{2}\right), 56.6\left(\mathrm{NCH}_{2}\right), 39.0\left(\mathrm{CH}_{2} \mathrm{NH}_{2}\right) ; \mathrm{m} / z 352.31$ $(\mathrm{M}+\mathrm{H}, 100 \%)$.

31. J. F. Burnett and R. E. Zahler, Chem. Rev. 1951, 49, 273-412.

32. C. Ma, Q. Zhang, K. Ding, L. Xin and D. Zhang, Tetrahedron Lett. 2007, 48, 7476-7479.

33. S. L. Hussey and B. R. Peterson, J. Am. Chem. Soc. 2002, 124, 6265-6273.

34. The lower yield obtained with $\mathbf{1 4}$ was due in part to handling problems during the work up of the reaction.

35. General method for the one-pot synthesis of 1-alkoxy-2arylaminoimidazolines. A solution of phenylisothiocyanate $(0.4 \mathrm{mmol}, 1$ equiv) in dry DMF $(2 \mathrm{~mL})$ was added dropwise to a stirred solution of amine ( 1.25 equiv $/ 0.5 \mathrm{mmol}$, or 2.5 equiv/ $1 \mathrm{mmol}$ for the reaction with diamines) in dry DMF (5 $\mathrm{mL}$ ) under an argon atmosphere. The resulting solution was stirred at room temperature until the starting material was consumed. Formation of the thiourea intermediate was checked by TLC and HPLC-MS. The deprotectioncyclization step was carried out by adding successively $\mathrm{PhSH}$ (5 equiv / nosyl group) and $\mathrm{K}_{2} \mathrm{CO}_{3}$ (10 equiv. / nosyl group) to the crude reaction. The resulting mixture was stirred at room temperature (typically $36 \mathrm{~h}$ ) checking the total disappearance of the starting material and the cyclization of the thiourea intermediate to the 1-alkoxy-2-imidazoline product by HPLC. In some cases, the cyclization step required mild heating $\left(65^{\circ} \mathrm{C}\right)$ during a few hours to go to completion. The solvent was removed in vacuo and the crude residue was dissolved in $\mathrm{CH}_{2} \mathrm{Cl}_{2}$ and washed successively with saturated $\mathrm{NaHCO}_{3}$ solution $(2 \times)$ and brine. The organic extracts were dried $\left(\mathrm{MgSO}_{4}\right)$ and evaporated in vacuo. The crude product was purified by silica chromatography with $\mathrm{CH}_{2} \mathrm{Cl}_{2} / \mathrm{MeOH}-\mathrm{NH}_{3 \text { sat }}$ Compound 12: brownish amorphous solid $(148 \mathrm{mg}, 74 \%) ; \mathrm{mp}>93{ }^{\circ} \mathrm{C} ; \delta_{\mathrm{H}}\left(300 \mathrm{MHz}, \mathrm{CDCl}_{3}\right)$ 7.47-7.30 (10H, m, Ar), $7.09(4 \mathrm{H}, \mathrm{d}, J 8.5 \mathrm{~Hz}, \mathrm{Ar}), 6.92(4 \mathrm{H}$, $\mathrm{d}, J 8.5, \mathrm{Ar}), 6.57(1 \mathrm{H}, \mathrm{s}, \mathrm{NH}), 5.29(2 \mathrm{H}, \mathrm{br} \mathrm{s}, \mathrm{NH}), 4.94(4 \mathrm{H}$, s, $\left.\mathrm{OCH}_{2}\right), 3.45(4 \mathrm{H}$, br t, $J 7.2), 3.25(4 \mathrm{H}$, br t, $J 7.2) ; \delta_{\mathrm{C}}(75$ $\left.\mathrm{MHz}, \mathrm{CDCl}_{3}\right) 159.5(\mathrm{C}=\mathrm{N}), 140.3(\mathrm{C}), 136.3(\mathrm{C}), 129.6(\mathrm{CH})$, 
$128.8(\mathrm{CH}), 128.7(\mathrm{CH}), 122.3(\mathrm{CH}), 118.2(\mathrm{CH}), 78.2$ $\left(\mathrm{OCH}_{2}\right), 52.7\left(\mathrm{NCH}_{2}\right), 45.8\left(\mathrm{NCH}_{2}\right) ; \mathrm{m} / \mathrm{z} 548.52(\mathrm{M}+\mathrm{H})$; HPLC: 93\%; Found: $\mathrm{C}, 65.21 ; \mathrm{H}, 6.38 ; \mathrm{N}$, 16.21. $\mathrm{C}_{32} \mathrm{H}_{33} \mathrm{~N}_{7} \mathrm{O}_{2} \cdot 2.3 \mathrm{H}_{2} \mathrm{O}$ requires $\mathrm{C}, 65.18 ; \mathrm{H}, 6.44 ; \mathrm{N}$, 16.63. Compound 13: brownish amorphous solid (174 mg, $48 \%$; mp $103-105^{\circ} \mathrm{C} ; \delta_{\mathrm{H}}\left(300 \mathrm{MHz}, \mathrm{CD}_{3} \mathrm{OD}\right) 7.01(4 \mathrm{H}, \mathrm{d}, J$ $8.7 \mathrm{~Hz}, \mathrm{Ar}), 6.88\left(4 \mathrm{H}, \mathrm{d}, J\right.$ 8.7, Ar), $3.67\left(6 \mathrm{H}, \mathrm{s}, \mathrm{OCH}_{3}\right), 3.32$ $(4 \mathrm{H}, \mathrm{m}), 3.2(4 \mathrm{H}, \mathrm{M}) ; \delta_{\mathrm{C}}\left(75 \mathrm{MHz}, \mathrm{CD}_{3} \mathrm{OD}\right) 160.4(C=\mathrm{N})$, $140.5(\mathrm{C}), 135.3(\mathrm{C}), 122.5(\mathrm{CH}), 117.9(\mathrm{CH}), 62.2\left(\mathrm{CH}_{3}\right)$, $51.1\left(\mathrm{CH}_{2}\right), 43.7\left(\mathrm{CH}_{2}\right) ; \mathrm{m} / \mathrm{z} 396.4(\mathrm{M}+\mathrm{H})$; HPLC: $98 \%$. Compound 14: brownish solid $(83 \mathrm{mg}, 42 \%)$; mp $78-82{ }^{\circ} \mathrm{C}$; $\delta_{\mathrm{H}}\left(300 \mathrm{MHz}, \mathrm{DMSO}-\mathrm{d}_{6}\right) 7.99(1 \mathrm{H}, \mathrm{br} \mathrm{s}, N H), 7.34(4 \mathrm{H}, \mathrm{d}, J$ $8.7 \mathrm{~Hz}, \mathrm{Ar}), 6.96(4 \mathrm{H}, \mathrm{d}, J 8.7, \mathrm{Ar}), 3.98(4 \mathrm{H}, \mathrm{q}, J 7), 3.5-3.4$ $(8 \mathrm{H}, \mathrm{m}), 1.23(6 \mathrm{H}, \mathrm{t}, J 7) ; \delta_{\mathrm{C}}\left(75 \mathrm{MHz}, \mathrm{DMSO}-\mathrm{d}_{6}\right) 159.1$ $(C=\mathrm{N}), 139.8(C), 133.0(C), 122.3(\mathrm{CH}), 117.2(\mathrm{CH}), 70.4$
$\left(\mathrm{CH}_{2}\right), 52.0\left(\mathrm{CH}_{2}\right), 44.5$ (br, $\left.\mathrm{CH}_{2}\right), 13.8\left(\mathrm{CH}_{3}\right) ; \mathrm{m} / \mathrm{z} 424$ $(\mathrm{M}+\mathrm{H})$; HPLC: $97 \%$. Compound 15: brownish amorphous solid (47 mg, 56\%); mp $>80{ }^{\circ} \mathrm{C} ; \delta_{\mathrm{H}}\left(300 \mathrm{MHz}, \mathrm{CDCl}_{3}\right) 7.33$ $(4 \mathrm{H}, \mathrm{d}, J 8.7 \mathrm{~Hz}, \mathrm{Ar}), 6.94(4 \mathrm{H}, \mathrm{d}, J 8.7, \mathrm{Ar}), 5.55(1 \mathrm{H}, \mathrm{br} \mathrm{s}$, $\mathrm{NH}), 5.28(2 \mathrm{H}, \mathrm{s}, \mathrm{NH}), 4.86(2 \mathrm{H}, \mathrm{br} \mathrm{m}, \mathrm{OCH}), 4.13(2 \mathrm{H}, \mathrm{m}$, $\left.\mathrm{OCH}_{2}\right), 3.75-3.55\left(8 \mathrm{H}, \mathrm{m}, \mathrm{NCH}_{2} \mathrm{CH}_{2} \mathrm{~N}+\mathrm{OCH}_{2}\right), 3.30(2 \mathrm{H}, \mathrm{d}$, $J$ 8.3, $\left.\mathrm{CH}_{2} \mathrm{~N}\right), 1.89-1.81(4 \mathrm{H}, \mathrm{m}), 1.57\left(8 \mathrm{H}\right.$, br m); $\delta_{\mathrm{C}}(75$ $\left.\mathrm{MHz}, \mathrm{CDCl}_{3}\right) 159.6(\mathrm{C}=\mathrm{N}), 138.6(\mathrm{C}), 133.6(\mathrm{C}), 119.8(\mathrm{CH})$, $118.4(\mathrm{CH}), 104.6(\mathrm{OCH}), 65.8\left(\mathrm{OCH}_{2}\right), 53.9\left(\mathrm{NCH}_{2}\right), 49.2$ $\left(\mathrm{NCH}_{2}\right), 29.3\left(\mathrm{CH}_{2}\right), 24.8\left(\mathrm{CH}_{2}\right), 21.4\left(\mathrm{CH}_{2}\right) ; \mathrm{m} / z 536.51$ $(\mathrm{M}+\mathrm{H})$; HPLC: $93 \%$.

36. In this case, the reaction should be carefully monitored (i.e., avoid high temperature and prolonged reaction times) to avoid the formation of dealkylation products. 